\title{
Assessment of Heavy Metal Pollution in the Blyde and Steelpoort Rivers of the Olifants River System, South Africa
}

\author{
Abraham Addo-Bediako* \\ Department of Biodiversity, University of Limpopo, Sovenga, South Africa
}

Received: 1 August 2019

Accepted: 25 September 2019

\begin{abstract}
The Olifants River System has been subjected to prolonged and cumulative ecosystem stress as a result of human activities such as mining, agriculture, industry and human settlements in the catchment. The objectives of the study were to assess pollution in the water and sediment by seven heavy metals and possible sources of pollution in two major tributaries of the Olifants River: the Blyde and Steelpoort rivers. The mean concentrations of the seven heavy metals in the water were low. The mean concentrations in the sediments were very high in both rivers. The results showed high levels of As and $\mathrm{Mn}$ in the Blyde River, and $\mathrm{Cr}, \mathrm{Fe}, \mathrm{Mn}$ and $\mathrm{Zn}$ in the Steelpoort River. The As and Mn in the Blyde could be from fertilizers, pesticides and other agricultural products, and $\mathrm{Cr}, \mathrm{Fe}, \mathrm{Mn}$ and $\mathrm{Zn}$ in the Steelpoort could be mainly from mining and agricultural discharge. The sediment analyses indicated a highly significant difference between the two rivers with the exception of $\mathrm{As}$ and $\mathrm{Pb}$. The results of the enrichment factor (EF) and geo-accumulation index (Igeo) indicated pollution by $\mathrm{Mn}$ and $\mathrm{Cr}$ in the Blyde, and $\mathrm{Cr}, \mathrm{Fe}, \mathrm{Mn}, \mathrm{Ni}$ and $\mathrm{Zn}$ in the Steelpoort. Thus, the results showed that there was a greater accumulation of heavy metals in the sediments of the Steelpoort than in the Blyde. The study demonstrates the need for a holistic approach to monitor pollution in the Steelpoort and a comprehensive strategy to prevent health risks in humans - especially communities that rely on the river for water and food.
\end{abstract}

Keywords: enrichment factor, geo-accumulation index, heavy metal pollution, sediment quality

\section{Introduction}

Globally, freshwater ecosystems have been subjected to several types of pollution mainly from anthropogenic activities such as mining, agriculture and industry [1-3]. In addition, urbanization and other human activities are

*e-mail: abe.addo-bediako@ul.ac.za contributors of pollution in water bodies [4]. Among the most serious water pollutants are heavy metals, which can have deleterious effects on aquatic organisms and humans, even at trace concentrations [5-7].

Heavy metals are easily adsorbed to sediments, which can act as a sink and secondary source of these contaminants in water and aquatic biota [8]. Heavy metals are known for their toxicity and persistence in the environment [9]. Metals also have the tendency 
to bio-accumulate in living tissues, such as fish, to concentrations that can compromise the normal physiological processes of these organisms and those that feed on them such as humans [10].

South Africa is experiencing a steep increase in water demand with three major sectors driving the demand, agriculture, municipal and industrial sectors. The Olifants River is one of the major river systems in South Africa. It provides water for industrial, agricultural and domestic use. However, due to the various activities in its catchment, the river has turned out to be one of the most polluted rivers in the country [11]. Many of the impoundments and tributaries of the river's system are said to be contaminated with heavy metals, inorganic nutrients such as sulphates and nitrates from agricultural fields, mine drainage and wastewater treatment plants [12].

The Blyde and Steelpoort rivers are important tributaries of the Olifants [13]. The Blyde is known for its continuous flow and good water quality and provides water mainly for agricultural and domestic purposes [14]. The Steelpoort has been impacted by anthropogenic activities in the catchment - especially mining (e.g., ferrochrome and platinum), agriculture and human settlements. The increasing activities in the catchments has resulted in the release of pollutants into the rivers, including heavy metals [2].

The study was conducted to assess heavy metal pollution in water and sediments of the two rivers, to investigate the degree of contamination and pollution using pollution indices such as enrichment factor (EF) and geo-accumulation index (Igeo), and to identify pollution patterns (if any) across study sites. Comparative study of these two rivers is important to prioritise pollutants entering the Olifants River from catchment areas. This is essential in designing proper management programmes to monitor water quality of the rivers as human activities continue to increase in the catchments.

\section{Materials and Methods}

\section{Study Area and Description}

The study was undertaken at two tributaries (Blyde and Steelpoort rivers) of the Olifants River (Fig. 1). Seven sampling sites were selected in the Blyde: Site 1 (BS1): Swadini Resort 24.516 S, 30.799 E; Site 2 (BS2): 24.504 S, 30.836 E; Site 3 (BS3): near a commercial farm (24.311 S, 30.834 E); Site 4 (BS4): near Hoedspruit town (24.405 S, 30.798 E); Site 5 (BS5): near a citrus farm (24.325 S, $30.831 \mathrm{E})$; Site 6 (BS6): near a wildlife estate (24.384 S, 30.806 E); and Site 7 (BS7): the confluence with the Olifants River, near an estate (24.258 S, 30.837 E). Sites represent four different groups of land use practices: domestic (BS1 \& BS2), agricultural (BS3 and BS4), industrial (BS5) and 'pristine' areas (BS6 and BS7). Four sites were selected in the Steelpoort on the basis of catchment characteristics and land use activities: Site 1 (SS1) is located upstream of the river

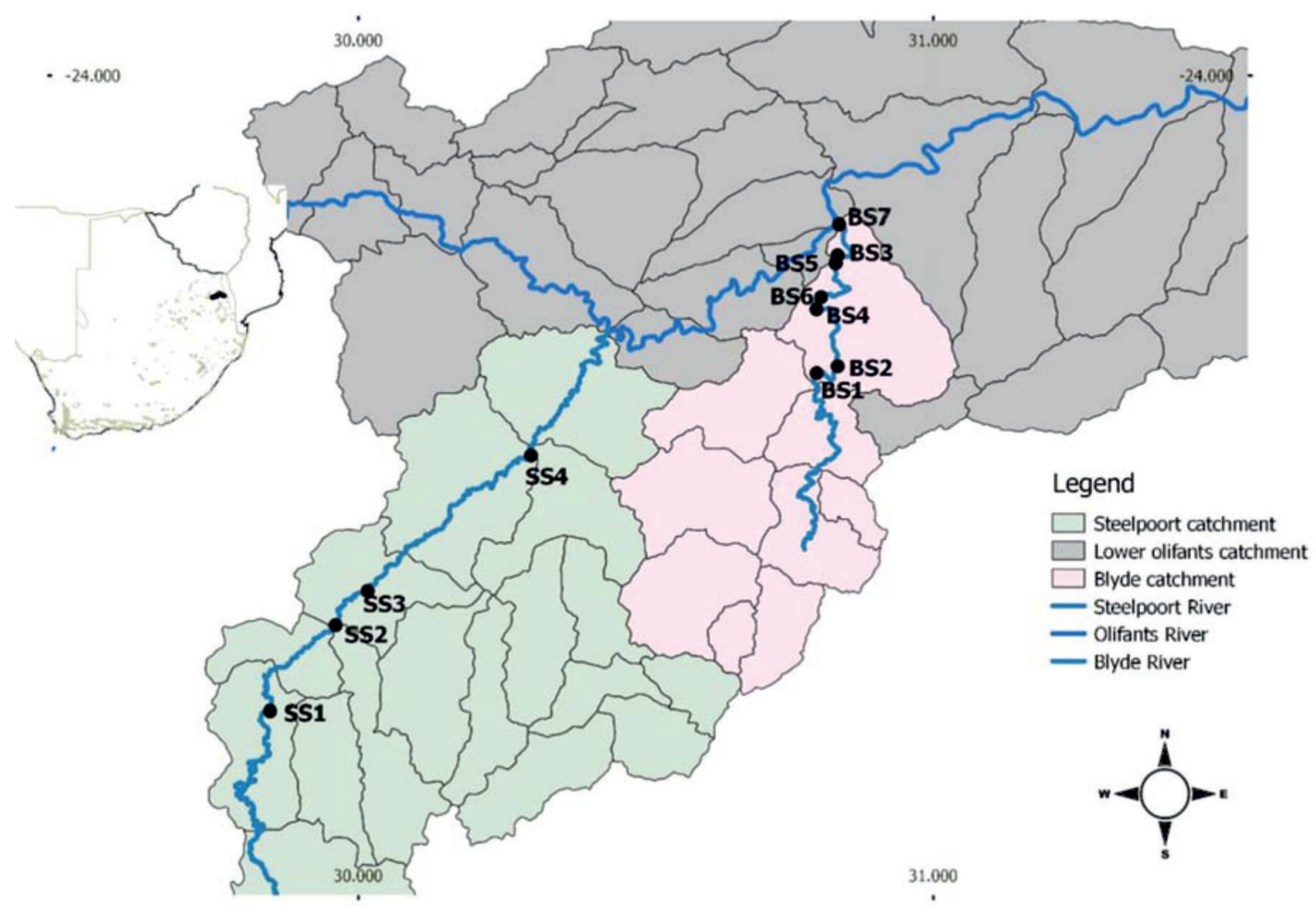

Fig. 1. Map of the study area showing the location of the seven sampling sites in the Blyde and four sampling sites in the Steelpoort of the Olifants River System. 
with little agricultural activity (25.101 S, 29.847 E); Site 2 (SS2) is near a mine (24.953 S, 29.961 E); Site 3 (SS3) is near a mine and metal smelter $(24.894 \mathrm{~S}, 30.017 \mathrm{E})$; and Site 4 (SS4) is near Steelpoort town close to the smelter (24.659 S, 30.302 E).

\section{Water and Sediment Sampling}

Water and sediment samples were collected bimonthly from January to November 2018 at seven sites in the Blyde and four sites in the Steelpoort. Water samples were collected in $100 \mathrm{ml}$ acid pre-treated polyethylene bottles and stored in a refrigerator $\left(4^{\circ} \mathrm{C}\right)$ prior to analysis. Physicochemical constituents of water such as temperature, $\mathrm{pH}$, dissolved oxygen, total dissolved solids (TDS), electrical conductivity and salinity were measured in the field using YSI equipment (Model 554 Datalogger with a 4 $\mathrm{m}$ multiprobe).

Surface sediment samples were collected at a depth of 0-10 $\mathrm{cm}$ using a hand trowel. Three to five samples were taken and composited before being transferred to the $500 \mathrm{ml}$ acid pre-treated polyethylene sampling bottles. The samples were placed in plastic bags, transported to the laboratory and frozen prior to analysis. Sediment samples were dried, and metal concentrations determined using nitric acid digestion and analysed by inductively coupled plasma-optical emission spectrometry (ICP-OES). Measurements were reported in $\mathrm{mg} / \mathrm{kg}$ dry weight by an accredited chemical laboratory (WaterLab (Pty) Ltd).

\section{Assessment of Sediment Contamination}

The degree of contaminants in the river was evaluated using an enrichment factor (EF). Iron $(\mathrm{Fe})$ was used as the normalizing element to determine the EF-values [15] using the formula:

\section{Enrichment factor} $=\left(\mathrm{C}_{\mathrm{n}} / \mathrm{Fe}\right)$ sample $/\left(\mathrm{C}_{\mathrm{n}} / \mathrm{Fe}\right)$ background

...where $\mathrm{C}_{\mathrm{n}}$ is the concentration of element " $\mathrm{n}$ ". The background value is that of average shale [16]. Elements which are naturally derived have an EF value of near unity, while elements of anthropogenic origin have EF values of several orders of magnitude. Six categories are recognised: $<1$ background concentration, 1-2 depletion to minimal enrichment, 2-5 moderate enrichment, 5-20 significant enrichment, 20-40 very high enrichment and $>40$ extremely high enrichment [17].

The geo-accumulation index (Igeo) values were calculated for the different elements [18] using the formula:

$$
\text { Igeo }=\log _{2}\left(\mathrm{C}_{\mathrm{n}} / 1.5 \mathrm{~B}_{\mathrm{n}}\right)
$$

...where $\mathrm{C}_{\mathrm{n}}$ is the measured concentration of an element in the sediment and $\mathrm{B}_{\mathrm{n}}$ is the geochemical background value in average shale of the element $\mathrm{n}$, and 1.5 is the background matrix correction due to Terrigenous effects. The geo-accumulation index

Table 1. Mean metal concentrations (mg/l) of Blyde and Steelpoort river water.

\begin{tabular}{|c|c|c|c|c|c|c|c|}
\hline Metal & $\mathrm{As}$ & $\mathrm{Cr}$ & $\mathrm{Fe}$ & $\mathrm{Mn}$ & $\mathrm{Ni}$ & $\mathrm{Pb}$ & $\mathrm{Zn}$ \\
\hline BS1 & 0.007 & 0.008 & 0.08 & 0.02 & 0.10 & 0.001 & 0.012 \\
\hline BS2 & 0.004 & 0.003 & 0.07 & 0.01 & 0.06 & 0.001 & 0.008 \\
\hline BS3 & 0.006 & 0.016 & 0.01 & 0.03 & 0.03 & 0.002 & 0.005 \\
\hline BS4 & 0.007 & 0.005 & 0.02 & 0.05 & 0.12 & 0.001 & 0.017 \\
\hline BS5 & 0.004 & 0.008 & 0.03 & 0.07 & 0.03 & 0.001 & 0.006 \\
\hline BS6 & 0.009 & 0.009 & 0.03 & 0.08 & 0.05 & 0.002 & 0.004 \\
\hline BS7 & 0.001 & 0.005 & 0.09 & 0.07 & 0.14 & 0.002 & 0.017 \\
\hline SS1 & 0.006 & 0.002 & 0.23 & 0.06 & 0.09 & 0.002 & 0.034 \\
\hline SS2 & 0.003 & 0.005 & 0.21 & 0.03 & 0.026 & 0.001 & 0.054 \\
\hline SS3 & 0.003 & 0.009 & 0.40 & 0.05 & 0.030 & 0.002 & 0.031 \\
\hline SS4 & 0.003 & 0.004 & 0.31 & 0.04 & 0.046 & 0.002 & 0.037 \\
\hline Guideline & $0.01^{1} ; 0.005^{3} ;$ & Cr III: $0.012^{1} ;$ & $0.3^{3}$ & $0.18^{1} ;<1.3^{2}$ & $<0.47^{4}$ & $0.0002-0.0012^{1} ;$ & $0.002^{1}, 0.03^{3}<0.12^{4}$ \\
values & $0.01^{4}$ & $0.0089^{3}$ & & & $0.007^{3}$ & $0.04-0.115^{2} ;$ \\
\hline
\end{tabular}

References:

$1-$ [20]

$2-[37]$

$3-[26]$

$4-[38]$ 
classification consists of seven classes (0-6): $<0$ (class 0 ) background concentration, 0-1 (class 1) unpolluted, 1-2 (class 2) moderately polluted, 2-3 (class 3) moderate to high pollution, 3-4 (Class 4) heavily polluted, 4-5 (Class 5) highly to very highly polluted, and 5-6 (Class 6) very heavily polluted [19].

\section{Results and Discussion}

\section{Heavy Metal Distribution in the Water}

The physicochemical parameters of water in both Blyde and Steelpoort rivers are presented in Table 1. Blyde acidity values ranged from 8.3 to 8.7 and were within the South African recommended range [20]. Mean electrical conductivity (EC): 270.75 at BS1 to $460.6 \mathrm{mS} / \mathrm{m}$ at BS4; total dissolved solids (TDS): 132.9 at $\mathrm{BS} 1$ to $152.9 \mathrm{mg} / \mathrm{l}$ at $\mathrm{BS} 7$; and dissolved oxygen (DO): 8.7 at BS5 to $11.5 \mathrm{mg} / 1$ at BS1. Steelpoort acidity ranged from 7.8 at SS1 to 9.0 at SS5. EC: 191.7 at SS2 to $446.5 \mathrm{mS} / \mathrm{m}$ at SS5; TDS: 90.8 at SS2 to $214.8 \mathrm{mg} / 1$ at SS3; and DO: 8.6 at SS3 to $10.7 \mathrm{mg} / 1$ at SS1. There were no significant differences in physicochemical properties between the two rivers $(p>0.05)$.

Mean metal concentration ranges of Blyde water were as follows: As 0.001 at BS7 to $0.009 \mathrm{mg} / 1$ at BS6; $\mathrm{Cr} 0.003$ at $\mathrm{BS} 2$ to $0.016 \mathrm{mg} / 1$ at $\mathrm{BS} 3$; $\mathrm{Fe} 0.01$ at $\mathrm{BS} 3$ to $0.09 \mathrm{mg} / 1$ at BS7; Mn 0.01 at BS2 to $0.08 \mathrm{mg} / 1$ at BS6; $\mathrm{Ni} 0.03$ at BS3 and BS5 to $0.14 \mathrm{mg} / \mathrm{l}$ at $\mathrm{BS} 7 ; \mathrm{Pb} 0.001$ to $0.02 \mathrm{mg} / \mathrm{l}$; and $\mathrm{Zn} 0.004$ at BS6 to $0.017 \mathrm{mg} / \mathrm{l}$ at BS4 and BS7.

The mean metal concentration ranges of Steelpoort water were as follows: As was $0.003 \mathrm{mg} / 1$ at all sites except SS1 (0.006 mg/1), Cr 0.002 at SS1 to $0.009 \mathrm{mg} / 1$ at $\mathrm{SS} 3, \mathrm{Fe} 0.21$ at $\mathrm{SS} 2$ to $0.40 \mathrm{mg} / 1$ at SS3, Mn 0.03 at
$\mathrm{SS} 2$ to $0.06 \mathrm{mg} / 1$ at $\mathrm{SS} 1, \mathrm{Ni} 0.026$ at SS1 to $0.046 \mathrm{mg} / 1$ at SS4, $\mathrm{Pb} 0.001$ to $0.002 \mathrm{mg} / 1$, and $\mathrm{Zn} 0.031$ at SS3 to $0.054 \mathrm{mg} / 1$ at SS2. There were no significant differences in metal concentrations between the two rivers (Table 1).

The source of high metal concentrations in the water could be natural (sediments in the case of environmental change) or from effluents of anthropogenic activities [21]. The water column and sediment layer are in direct contact, leading to an exchange of constituents, including metals [22]. In the Steelpoort, the high mean concentrations of $\mathrm{Cr}$ and $\mathrm{Fe}$ could be from Ferrochrome mining discharge, while the relatively higher As concentration in the Blyde could have come from fertilizers and pesticides due to the intensive agricultural activities in some parts of the catchment [23].

\section{Heavy Metal Distribution in the Sediments}

Mean heavy metal concentration ranges in Blyde sediment were as follows: As 1.4 at BS5 to $4.05 \mathrm{mg} / \mathrm{kg}$ at BS7, Fe 9457 at BS3 to $64771 \mathrm{mg} / \mathrm{kg}$ at BS7, Mn 280 at $\mathrm{BS} 5$ to $1016 \mathrm{mg} / \mathrm{kg}$ at $\mathrm{BS} 4$, Ni 9.84 at BS3 to 55.0 $\mathrm{mg} / \mathrm{kg}$ at $\mathrm{BS} 7, \mathrm{~Pb} 4.16$ at $\mathrm{BS} 1$ to $6.76 \mathrm{mg} / \mathrm{kg}$ at $\mathrm{BS} 3$, and $\mathrm{Zn} 16$ at BS6 to $69.1 \mathrm{mg} / \mathrm{kg}$ at BS4 (Table 2).

In the Steelpoort, As concentrations ranged from 1.03 at SS4 to $2.35 \mathrm{mg} / \mathrm{kg}$ at SS1, Fe 124917 at SS4 to $240528 \mathrm{mg} / \mathrm{kg}$ at SS2, Mn 1619 at SS3 to $2312 \mathrm{mg} / \mathrm{kg}$ at $\mathrm{SS} 2, \mathrm{Ni} 34$ at $\mathrm{SS} 1$ to $185 \mathrm{mg} / \mathrm{kg}$ at SS4, Pb 2.66 at $\mathrm{SS} 2$ to $3.66 \mathrm{mg} / \mathrm{kg}$ at SS3, and Zn 122 at SS2 to 215 $\mathrm{mg} / \mathrm{kg}$ at SS3 (Table 2). Similar to the water column, metal concentrations in sediments were higher in the Steelpoort except for $\mathrm{As}$ and $\mathrm{Pb}$.

The concentrations of $\mathrm{Cr}$ exceeded the Canadian Council of Ministers of the Environment (CCME)

Table 2. Comparison of heavy metal concentrations ( $\mathrm{mg} / \mathrm{kg}$, dry weight) in river sediments of the Blyde and Steelpoort rivers.

\begin{tabular}{|c|c|c|c|c|c|c|c|}
\hline Metal & As & $\mathrm{Cr}$ & $\mathrm{Fe}$ & $\mathrm{Mn}$ & $\mathrm{Ni}$ & $\mathrm{Pb}$ & $\mathrm{Zn}$ \\
\hline BS1 & 2.7 & 73.0 & 32899 & 607 & 38.0 & 4.16 & 49.0 \\
\hline BS2 & 1.7 & 50.0 & 28879 & 477 & 23.0 & 4.40 & 33.0 \\
\hline BS3 & 2.2 & 21.0 & 9457 & 437 & 9.8 & 6.80 & 20.0 \\
\hline BS4 & 2.9 & 62.0 & 49269 & 1016 & 50.0 & 5.50 & 69.3 \\
\hline BS5 & 1.4 & 30.0 & 10772 & 280 & 11.0 & 4.50 & 24.0 \\
\hline BS6 & 3.6 & 36.0 & 13050 & 699 & 19.0 & 5.90 & 16.0 \\
\hline BS7 & 4.1 & 218 & 64771 & 694 & 55.0 & 6.30 & 66.0 \\
\hline SS1 & 2.4 & 60.1 & 227827 & 2236 & 34.0 & 3.28 & 138 \\
\hline SS2 & 1.4 & 610 & 240528 & 2312 & 143 & 2.66 & 122 \\
\hline SS3 & 1.23 & 1461 & 137828 & 1619 & 121 & 3.66 & 215 \\
\hline SS4 & 1.03 & 477 & 124917 & 1717 & 185 & 3.55 & 149 \\
\hline Guideline value & na & $37.3^{1}$ & na & na & na & $35.0^{1}$ & $123^{1}$ \\
\hline
\end{tabular}

${ }^{1}-[26]$ 


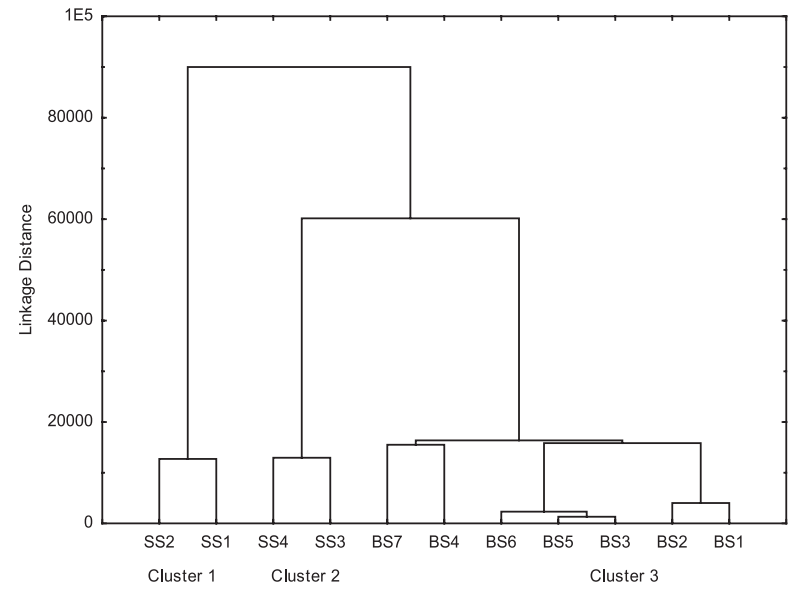

Fig. 2. Cluster diagram of sites obtained using the linkage method and Euclidean distance matrix (the distance reflects the degree of association between different sites based on the dissimilarity of metals of surface sediments).

sediment quality guidelines for the protection of aquatic life, which is $37.3 \mathrm{mg} / \mathrm{kg}$ at all sites for both rivers except at BS3, BS5 and BS6 along the Blyde. Similar to the water column, high concentrations of $\mathrm{Cr}$ at Steelpoort sites could be from ferrochrome mining discharge. Concentrations of $\mathrm{Zn}$ exceeded the CCME sediment quality guideline of $13 \mathrm{mg} / \mathrm{kg}$ at all sites of the Steelpoort River except site SS1. High concentrations of $\mathrm{Zn}$ in sediment from the Steelpoort may be attributed to the presence of unused remains of zinc sulphate in fertilizers [24] and wastewater [25].

A comparison of the mean concentration of heavy metals in sediments (Table 2) to CCME sediment quality guidelines [26] show that all Steelpoort study sites were heavily polluted with $\mathrm{Cr}(>37.3 \mathrm{mg} / \mathrm{kg})$ and $\mathrm{Zn}(>123 \mathrm{mg} / \mathrm{kg})$, while BS1, BS2 and BS4 of the Blyde were polluted with $\mathrm{Cr}$. High levels of $\mathrm{Cr}$ in the Blyde are not unexpected, as fertilizers usually contain significant contents of $\mathrm{Cr}$ [27].

Based on the spatial similarities of metal concentrations in the sediments, three main clusters were identified (Fig. 2). Cluster 1 comprised two sites of the Steelpoort (SS1 and SS2), with relatively lower metal concentrations in sediment samples. Cluster 2 also comprised the other two sites of the same river (SS3 and SS4), which are surrounded by heavy mining and smelter activities. Cluster 3 is comprised of all seven sites of the Blyde, depicting the main sources of pollution at these sites resulting from agricultural and domestic discharges.

\section{Enrichment Factor}

The degree of pollution in sediments can be assessed using indices such as enrichment factor (EF) and the geo-accumulation index. EF values for the metals together with their background average shale [16] are shown in Table 3. The EF index has been widely used to determine the pollution status and the sources of heavy metals in sediments of rivers, lakes and bays $[28,29]$. According to the EF classifications, most of the metals showed deficiency to minimal enrichment in both rivers. However, $\mathrm{Cr}$ shows moderate $(>2)$ to significantly high $(>5)$ enrichment downstream in the Steelpoort, while Mn shows a moderate $(>2)$ enrichment at BS3 and BS6 of the Blyde. Manganese compounds are used in fertilizers, varnishes, fungicides and as livestock feed supplements. Increased $\mathrm{Cr}$ values at SS3 and SS4 are strongly linked to the high ferrochrome mining associated with the catchment of the Steelpoort.

\section{Geo-Accumulation Index}

The geo-accumulation index is used to determine anthropogenic contamination in river sediments [30, 31]. The calculated Igeo values based on the average shale are presented in Table 4 and show that the majority of metals have an index value below zero. In the Blyde, all metals were below zero except $\mathrm{Cr}$ at site BS7, which had an Igeo value of between 0 and 1, and belongs to class 1 . This indicates that the river sediment is uncontaminated at all the sites, except BS7, where the river joins the Olifants - an indication that the contamination is mainly from the Olifants. However, in the Steelpoort, only $\mathrm{As}$ and $\mathrm{Pb}$ had Igeo values below zero at all sites. The Igeo value for $\mathrm{Cr}$ ranged

Table 3. Enrichment factor for heavy metal in Blyde and Steelpoort river sediments.

\begin{tabular}{|c|c|c|c|c|c|c|c|c|c|c|c|c|}
\hline Metal & Shale & BS1 & BS2 & BS3 & BS4 & BS5 & BS6 & BS7 & SS1 & SS2 & SS3 & SS4 \\
\hline $\mathrm{As}$ & 13 & 0.3 & 0.2 & 0.84 & 0.21 & 0.5 & 1.1 & 0.23 & 0.04 & 0.02 & 0.03 & 0.02 \\
\hline $\mathrm{Cr}$ & 90 & 1.16 & 0.91 & 1.2 & 0.66 & 1.5 & 1.5 & 1.8 & 0.14 & 1.3 & 5.6 & 2.1 \\
\hline $\mathrm{Fe}$ & 47200 & 1 & 1 & 1 & 1 & 1 & 1 & 1 & 1 & 1 & 1 & 1 \\
\hline $\mathrm{Mn}$ & 20 & 1.02 & 0.92 & 2.6 & 1.15 & 1.44 & 3.0 & 0.6 & 0.54 & 0.53 & 0.65 & 0.8 \\
\hline $\mathrm{Ni}$ & 850 & 0.8 & 0.55 & 0.72 & 0.7 & 0.71 & 1.1 & 0.6 & 0.1 & 0.41 & 0.6 & 1.03 \\
\hline $\mathrm{Pb}$ & 68 & 0.3 & 0.36 & 1.69 & 0.26 & 0.26 & 1.1 & 0.23 & 0.03 & 0.01 & 0.1 & 0.1 \\
\hline $\mathrm{Zn}$ & 95 & 0.74 & 0.57 & 1.1 & 0.7 & 0.7 & 0.61 & 0.51 & 0.3 & 0.3 & 0.8 & 0.6 \\
\hline
\end{tabular}


Table 4. Geo-accumulation index for heavy metals in Blyde and Steelpoort river sediments.

\begin{tabular}{|c|c|c|c|c|c|c|c|}
\hline IgeO & $\mathrm{As}$ & $\mathrm{Cr}$ & $\mathrm{Fe}$ & $\mathrm{Mn}$ & $\mathrm{Ni}$ & $\mathrm{Pb}$ & $\mathrm{Zn}$ \\
\hline $\mathrm{BS} 1$ & -2.80 & -0.88 & -1.10 & -1.10 & $-1,41$ & -2.90 & -1.60 \\
\hline $\mathrm{BS} 2$ & -3.51 & -1.42 & -1.31 & -1.43 & -2.10 & -2.14 & -2.10 \\
\hline BS3 & -3.23 & -2.61 & -2.87 & -1.60 & -3.33 & -2.23 & -2.52 \\
\hline BS4 & -2.69 & -1.13 & -0.48 & -0.32 & -0.96 & -2.50 & -1.13 \\
\hline BS5 & -3.48 & -2.23 & -2.71 & -2.20 & -3.22 & -2.67 & -2.58 \\
\hline BS6 & -2.49 & -1.90 & -2.52 & -0.89 & -2.40 & -2.41 & -3.20 \\
\hline BS7 & -2.40 & $\mathbf{0 . 6 8}$ & -0.15 & -0.91 & -0.90 & -2.40 & -1.10 \\
\hline SS1 & -3.12 & -1.21 & $\mathbf{1 . 7 0}$ & $\mathbf{0 . 8 5}$ & -1.62 & -3.23 & -2.31 \\
\hline SS2 & -0.50 & $\mathbf{2 . 2 1}$ & $\mathbf{1 . 8 2}$ & $\mathbf{0 . 8 5}$ & $\mathbf{0 . 5 0}$ & -0.15 & -0.20 \\
\hline SS3 & -4.10 & $\mathbf{3 . 4 1}$ & $\mathbf{0 . 9 6}$ & $\mathbf{0 . 4 0}$ & $\mathbf{0 . 2 6}$ & -3.10 & $\mathbf{0 . 6 1}$ \\
\hline SS4 & -4.32 & $\mathbf{1 . 8 2}$ & $\mathbf{0 . 5 5}$ & $\mathbf{0 . 4 3}$ & $\mathbf{0 . 8 5}$ & -3.20 & $\mathbf{0 . 1 0}$ \\
\hline
\end{tabular}

from 1.82 to 3.4 (class 1 to class 4). The Igeo value for Fe ranged from 0.55 to 1.82 (class 1 to class 2). The Igeo value for Mn ranged from 0.44 to 0.85 (class 1). The Igeo value for $\mathrm{Ni}$ was above zero from SS2 to $\mathrm{SS} 4$, and falls in class 1 . The Igeo value for $\mathrm{Zn}$ was above zero only at SS3 and SS4 (class 1). The calculated Igeo class values in the Steelpoort were between 0 and 4 and the Igeo class values showed uncontaminated to heavily contaminated river sediments, while in the Blyde the Igeo class values for $\mathrm{Cr}$ showed uncontaminated to moderately contaminated river sediments [19].

Comparing the two rivers, the Steelpoort is more contaminated with the selected metals than the Blyde. The high levels of metals such as, $\mathrm{Fe}, \mathrm{Cr}$ and $\mathrm{Zn}$ in the Steelpoort possibly originate from the smelting of ferrochrome in the area [2] and wastewater [32]. This is of great concern, as the levels of contaminants are likely to increase due to the rapid urbanization and industrialization in the area. Many studies have confirmed a link between urbanization and contamination by heavy metals in rivers [33-36].

\section{Conclusion}

Sediments actively accumulate heavy metals, which may somehow improve the quality of the water, but this phenomenon poses a risk of secondary water pollution by heavy metals under sediment disturbance and/or changes in sediment chemistry. The standard guideline, EF and Igeo values indicated widespread pollution by $\mathrm{Cr}, \mathrm{Fe}, \mathrm{Mn}$ and $\mathrm{Zn}$ in the Steelpoort sediments, and $\mathrm{Cr}$ and $\mathrm{Mn}$ in the Blyde sediments. In the Blyde, the Igeo values showed that sediments have background concentrations for all the metals except $\mathrm{Cr}$, while in the Steelport the Igeo values (with the exception of $\mathrm{As}$ and $\mathrm{Pb}$ ) exceeded the background concentrations.

\section{Acknowledgements}

The author is grateful to the Flemish Interuniversity Council (VLIR-UOS) funding of the project (VLIR/ Water). I am also thankful for the support of the postgraduate students in the Biodiversity Water Laboratory.

\section{Conflict of Interest}

The author declares no conflict of interest.

\section{References}

1. JUN Y-C., KIM N-Y., KIM S-H., PARK S-H., KONG D-S., HWANG, S-J. Spatial distribution of benthic macroinvertebrate assemblages in relation to environmental variables in Korean nationwide streams. Water 8, 1, 2016.

2. ADDO-BEDIAKO A., MATLOU K., MAKUSHU E. Heavy metal concentrations in water and sediment of the Steelpoort River, Olifants River System, South Africa. Afr. J. Aquat. Sci 43 (4), 413, 2018.

3. NIBA A., SAKWE S. Turnover of benthic macroinvertebrates along the Mthatha River, Eastern Cape, South Africa. Implications for water quality biomonitoring using indicator species. J. Freshwater Ecol. 33, 157, 2018.

4. LI Y., ZHANG H., CHEN X., TU C., LUO Y., CHRISTIE P. Distribution of heavy metals in soils of the Yellow River Delta: Concentrations in different soil horizons and source identification. J. Soil. Sediment. 14, 1158, 2014.

5. WEBER P., BEHR E.R., KNORR C.D.L., VENDRUSCOLO D.S. FLORES E.M.M. DRESSLER V.L., BALDISSEROTTO B. Metals in the water, sediment, and tissues of two fish species from different trophic levels in a subtropical Brazilian river. Microchem. J. 106, 61, 2013.

6. MARR S.M., JOOSTE A., ADDO-BEDIAKO A., LUUS-POWELL W.J. Are catfish from metal-polluted 
impoundments safe for human consumption? A case study of two impoundments in the Olifants River, South Africa. Inland Waters 5, 215, 2015.

7. VERHAERT V., TEUCHIES J., VLOK W., WEPENER V., ADDO-BEDIAKO A., JOOSTE A., BLUST R., BERVOETS L. Bioaccumulation and trophic transfer of total mercury in the subtropical Olifants River Basin, South Africa. Chemosphere 216, 832, 2018.

8. VAROL, M., SEN, B. Assessment of nutrient and heavy metal contamination in surface water and sediments of the upper Tigris River, Turkey. Catena 92, 1, 2012.

9. WIECZOREK-DĄBROWSKA M., TOMZAMARCINIAK A., PILARCZYK B., BALICKA-RAMISZ A. Roe and red deer as bioindicators of heavy metals contamination in north-western Poland. Chem. Ecol. 29, 100, 2013.

10. JOOSTE A., MARR S.M., ADDO-BEDIAKO A., LUUSPOWELL W.J. Sharptooth catfish shows its metal: a case study of metal contamination at two impoundments in the Olifants River, Limpopo river system, South Africa. Ecotox. Environ. Safe. 112, 96, 2015.

11. ADDO-BEDIAKO A., MARR S., JOOSTE A., LUUSPOWELL W.J. Are metals in the muscle tissue of Mozambique tilapia a threat to human health? A case study of two impoundments in the Olifants River, Limpopo, South Africa. Int. J. Limnol. 50, 201, 2014.

12. OBERHOLSTER P.J., BOTHA A., CHAMIER J., DE KLERK A.R. Longitudinal trends in water chemistry and phytoplankton assemblage downstream of the rivers WWTP in the upper Olifants River. Ecohydrol. Hydrobiol. 13, 41, 2013

13. JOOSTE A., LUUS-POWELL W., ADDO-BEDIAKO A. The impact of water and sediment quality on the health of fish and the diversity of fish parasites in two impoundments of the Olifants River, Limpopo Province. Project, by Water Research Commission and University of Limpopo. Report No: K5/1929. WRC, Pretoria. pp247, 2015.

14. RAVEN B.W. Water affairs in the Lower Blyde River: The role of DWAF in local water management. IMWI Working Paper. IMWI, Wageningen, 2004.

15. LOSKA K., WIECHULA D., KORUS I. Metal contamination of farming soils affected by industry. Environ. Int. 30, 159, 2003.

16. TUREKIAN K.K., WEDEPOHL K.H. Distribution of the elements in some major units of the earth's crust. Geol. Soc. Am. Bull. 72, 175, 1961.

17. SUTHERLAND R.A. Bed-sediment associated trace metals in an urban stream, Oahu, Hawaii. Environ. Geol. 39, 611, 2000.

18. MULLER G. Index of Geo-Accumulation in Sediments of the Rhine River. GeoJournal 2, 108, 1969.

19. BARBIERI M. The Importance of Enrichment Factor (EF) and Geoaccumulation Index (Igeo) to Evaluate the Soil Contamination. J. Geol. Geophy. 5, 1, 2016.

20. DWAF (DEPARTMENT OF WATER AFFAIRS AND FORESTRY) South African Water Quality Guidelines, Volume 7: Aquatic Ecosystems, Department of Water Affairs and Forestry, Pretoria, South Africa, 1996.

21. RZETALA M.A. Assessment of toxic metal contamination of bottom sediments in water bodies in urban areas. Soil Sedim. Contam. Int. J. 24, 49, 2015.

22. IGNATAVIČIUSA G., VALSKYSA V., BULSKAYAB I., PALIULISC D., ZIGMONTIENE A., SATKŪNAS J. Heavy metal contamination in surface runoff sediments of the urban area of Vilnius, Lithuania. Est. J. Earth Sci. 66, 13, 2017.
23. WEI B., YANG L. A review of heavy metal contaminations in urban soils, urban road dusts and agricultural soils from China. Microchem. J. 94, 99, 2010.

24. REZA R., SINGH G. Heavy metal contamination and its indexing approach for river water. International J. Environ. Sci. Technol. 7, 785, 2010.

25. SOJKA M., JASKUŁA J., SIEPAK M. Heavy Metals in Bottom Sediments of Reservoirs in the Lowland Area of Western Poland: Concentrations, Distribution, Sources and Ecological Risk. Water 11, 56, 2019.

26. CCME (CANADIAN COUNCIL OF MINISTERS OF THE ENVIRONMENT). Canadian water quality guidelines for the protection of aquatic life and sediment quality guidelines for the protection of aquatic life.in. Canadian Council of Ministers of the Environment, 2012.

27. KRÜGER O., FIEDLER F., ADAM C., VOGEL C., SENZ R. Determination of chromium (VI) in primary and secondary fertilizer and their respective precursors. Chemosphere 182, 48, 2017.

28. BRADY J.P., AYOKO G.A., MARTENS W.N., GOONETILLEKE A. Enrichment, distribution and sources of heavy metals in the sediments of Deception Bay, Queensland. Australia Mar. Pollut. Bull. 81 (1), 248, 2014.

29. GAO C., LIN Q., BAO K., ZHAO H., ZHANG Z., XING W., WANG G. Historical variation and recent ecological risk of heavy metals in wetland sediments along Wusuli River, Northeast China. Environ. Earth Sci. 72 (11), 4345, 2014.

30. GUPTA S., VINOD J., MATIC N., KAPRALOVA V., SOLANKI J. Assessment of Geo-Accumulation Index of Heavy Metal and Source of Contamination by Multivariate Factor Analysis. Int. J. Hazard. Mater. 18, 18, 2014.

31. JI H., LI H., ZHANG Y., DING H., GAO Y., XING Y. Distribution and risk assessment of heavy metals in overlying water, porewater, and sediments of Yongding River in a coal mine brownfield. J. Soil. Sediment. 18, 624, 2018.

32. XU L., WANG T., NI K., LIU S., WANG P., XIE S., MENG J., ZHENG X., LU Y. Metals contamination along the watershed and estuarine areas of southern Bohai Sea, China. Mar. Pollut. Bull. 74, 453, 2013.

33. ABUDUWAILI J., ZHANG Z.Y., JIANG F.Q. Assessment of the distribution, sources and potential ecological risk of heavy metals in the dry surface sediment of Aibi Lake in Northwest China. PLOS ONE, 10 (3), e0120001, 2015.

34. CHEN H., CHEN R., TENG Y., WU J. Contamination characteristics, ecological risk and source identification of trace metals in sediments of the Le'an River (China). Ecotox. Environ. Safe. 125, 85, 2016.

35. STALEY C., JOHNSON D., GOULD T.J., WANG P., PHILliPS J., COTNER J.B., SADOWSKY M.J. Frequencies of heavy metal resistance are associated with land cover type in the Upper Mississippi River. Sci. Total Environ. 511, 461, 2015.

36. ZHANG Z., JUYING L., MAMAT Z., QINGFU Y. Sources identification and pollution evaluation of heavy metals in the surface sediments of Bortala River, Northwest China. Ecotox. Environ. Safe. 126, 94, 2016.

37. BCEPD (BRITISH COLUMBIA ENVIRONMENTAL PROTECTION DIVISION) Water quality - a compendium of working water quality guidelines for British Columbia, 2006.

38. USEPA (UNITED STATES ENVIRONMENTAL POTECTION AGENCY) National recommended water quality criteria: Aquatic life. in, United States Environmental Protection Agency, 2012. 
